\title{
UJI AKTIVITAS ANTIOKSIDAN DAUN KERSEN (Muntingia calabura L.) DENGAN METODE DPPH (1,1-difenil-2-pikrilhidrazil) DAN FRAP (Ferric Reducing Antioxidan Power)
}

\author{
Fitriyanti Jumaetri Sami ${ }^{1}$, Syamsu Nur ${ }^{2}$, Naimah Ramli ${ }^{2}$, Budi Sutrisno ${ }^{1}$ \\ ${ }^{1}$ Sekolah Tinggi Ilmu Farmasi Makassar \\ ${ }^{2}$ Akademi Farmasi Kebangsaan Makassar \\ Email : fitriyantijumaetri sami@yahoo.com
}

\begin{abstract}
Has conducted research of antioxidant activity from kersen leaves (Muntingia calabura Linn) using DPPH (1,1-diphenyl-1-picrilhydrazil) and FRAP (Ferric Reducing Antioxidant Power). Kersen leaves extracted by maceration using ethanol $70 \%$. Phytochemical identification of kersen leaves contain phenolic, flavonoids and saponins compounds. The test results of antioxidant activity using DPPH method with series concentrations of $2,4,6,8$, and $10 \mathrm{ppm}$ obtain $I C_{50}$ value $6.8249 \mathrm{ug} / \mathrm{ml}$. Testing of the ethanol extract of antioxidants obtained by FRAP method IC $C_{50} 83,149$ $\mu M$. Based on these data the ethanol extract of kersen leaves has good antioxidant activity.
\end{abstract}

Key words: Antioxidant, daun kersen (Muntingia calabura Linn.), DPPH methods and FRAP methods.

\section{PENDAHULUAN}

Radikal bebas adalah atom atau molekul yang tidak stabil dan sangat reaktif karena mengandung satu atau lebih elektron tidak berpasangan pada orbital terluarnya. Maka untuk mencapai kestabilannya, akan bereaksi dengan molekul disekitarnya untuk memperoleh pasangan elektron. Reaksi ini akan berlangsung secara terus-menerus dalam tubuh dan apabila tidak dihentikan dapat merusak sel sehingga sangat berbahaya bagi kesehatan serta akan menimbulkan berbagai penyakit seperti kanker, jantung, katarak, penuaan dini, serta penyakit degeneratif lainnya. ${ }^{1}$

Radikal bebas dapat mengganggu integritas sel dan dapat bereaksi dengan komponenkomponen sel, baik komponen struktural meliputi molekul-molekul penyusun membran maupun komponen fungsional meliputi protein, enzim-enzim, dan DNA. ${ }^{2}$ Radikal bebas dapat dijumpai pada lingkungan, beberapa logam misalnya 
Uji aktivitas antioksidan daun kersen (Muntingia calabura L.) dengan metode DPPH dan FRAP

besi dan tembaga, asap rokok, polusi udara, obat, bahan beracun, makanan dalam kemasan, bahan aditif, dan sinar ultraviolet matahari yang menyebabkan radiasi. Reaktifitas radikal bebas itu dapat dihambat oleh sistem antioksidan yang merupakan bagian dari sistem kekebalan tubuh. $^{3}$

Salah satu tanaman yang dapat dimanfaatkan sebagai tanaman obat adalah kersen (Muntingia calabura L.). Daun kersen berkhasiat sebagai obat batuk dan peluruh dahak, buah yang telah masak dapat digunakan untuk sakit kuning dilaporkan bahwa kersen yang mengandung flavonoid mempunyai khasiat hipotensi, dan antiseptic. ${ }^{4,5}$

Nutrisi tanaman kersen per 100 g adalah air, protein, lemak, serat, kalsium, fosfor, karoten, vitamin B1, B2, B3 dan C. Kandungan senyawa aktif tanaman kersen adalah flavonoid, sesquiterpenoid dan derivat furan. ${ }^{6}$

Berdasarkan data tersebut pada penelitian ini dilakukan uji aktivitas antioksidan ekstrak etanol daun kersen (Muntingia calabura L.) dengan menggunakan metode DPPH (1,1difenil-2-pikrilhidrazil) dan FRAP (Ferric Reducing Antioksidan Power).

\section{METODE PENELITIAN}

\section{Alat dan Bahan}

Alat yang digunakan adalah Timbangan analitik, aluminium foil, kertas saring Whatman no 42, spektrofotometer UV-Vis, labu ukur, oven, pipet tetes, sendok tanduk, rotavapor, cawan Porselin, Erlenmeyer, tabung reaksi, rak tabung, batang pengaduk, mikro pipet, alat maserasi dan alat - alat lain yang menunjang penelitian ini.

Bahan yang digunakan adalah daun Kersen, etanol 96\%, H2SO4 pekat, $\mathrm{HCl}$ pekat, $\mathrm{FeCl}_{3} 1 \%$, TPTZ, $\mathrm{FeSO}_{4}$. serbuk $\mathrm{Mg}$, asam asetat glasial, 1,1-difenil-2-pikrilhidrazil (DPPH).

\section{Prosedur Penelitian}

\section{Uji Fitokimia}

\section{Pengujian Fenolik}

Sebanyak $5 \mathrm{ml}$ ekstrak ditambahkan 10 tetes $\mathrm{FeCl}_{3}$ 1\%. Uji Positif ekstrak mengandung fenol terbentuk menghasilkan warna hitam pekat.

\section{Pengujian Flavonoid}

Sebanyak $5 \mathrm{ml}$ ekstrak ditambahkan dengan $2 \mathrm{~mL}$ air panas, didihkan selama 5 menit, kemudian disaring. Filtrat sebanyak $5 \mathrm{~mL}$ ditambahkan 0,05 mg serbuk $\mathrm{Mg}$ dan $1 \mathrm{~mL} \mathrm{HCl}$ pekat, kemudian dikocok kuat-kuat. Uji positif ditunjukkan 
Uji aktivitas antioksidan daun kersen (Muntingia calabura L.) dengan metode DPPH dan FRAP

dengan terbentuknya warna merah, kuning atau jingga.

\section{Pengujian Saponin}

Dipipet sebanyak $5 \mathrm{ml}$ ekstrak lalu ditambahkan 2 tetes $\mathrm{HCl} 1 \mathrm{~N}$. Terbentuk busa dan tetap stabil \pm 7 menit, maka ekstrak positif mengandung saponin.

\section{Uji Aktivitas Antioksidan}

\section{Pembuatan larutan Sampel}

Dibuat Iarutan uji dalam berbagai konsentrasi dengan induk 100 ppm ekstrak daun kersen (muntingia calabura L.) dari larutan induk tersebut dibuat seri konsentrasi yaitu 2 ppm, 4 ppm, 6 ppm, 8 ppm, dan 10 ppm.

Pembuatan Larutan Stok DPPH 0,4 $\mathrm{mM}$

Ditimbang DPPH sebanyak 0,01577 g dan dilarutkan dengan etanol pro analisis hingga $100 \mathrm{ml}$ dalam labu ukur sehingga diperoleh larutan dengan konsentrasi 0,4 mM.

\section{Pengukuran Serapan Larutan Blanko DPPH}

Larutan DPPH dipipet sebanyak $1 \mathrm{ml}$ dan ditambahkan $4 \mathrm{ml}$ etanol pro analisis dimasukkan kedalam vial, larutan ini kemudian diukur dengan Spektrofotometri UV-Vis pada panjang gelombang maksimum.

\section{Pengukuran Aktivitas Pengikatan Ekstrak Etanol Daun Kersen Terhadap DPPH.}

Larutan seri konsentrasi 2 ppm, 4 ppm, 6 ppm, 8 ppm, 10 ppm dipipet masing-masing $1 \mathrm{ml}$ dan di tambahkan larutan 0,4 mM DPPH $1 \mathrm{ml}$. Larutan tersebut kemudian di cukupkan dengan etanol hingga $5 \mathrm{ml}$, dikocok dan didiamkan 30 menit di tempat gelap. Serapan diukur dengan spektrofotometri UV-Vis pada panjang gelombang 516-520 nm.

Nilai persentase inhibisi yang diwakili oleh nilai IC50 dihitung dengan rumus sebagai berikut :

$\%$ Inhibisi $=\frac{(\text { A Blanko }- \text { A Ekstrak })}{\text { A Blanko }} \times 100 \%$

Kemudian dibuat dalam kurva regresi linear untuk memperoleh nilai $I_{50}$

Pengukuran Aktivitas Antioksidan dengan Metode FRAP

\section{Pembuatan larutan Reagen}

a. Larutan $3 \mathrm{mM} \mathrm{FeCl}_{3}$ dalam asam sitrat $5 \mathrm{mM}(50 \mathrm{ml})$.

Dilarutkan $24.33 \mathrm{mg}$ serbuk $\mathrm{FeCl}_{3}$ dan dilarutkan dalam $50 \mathrm{ml}$ larutan asam sitrat $5 \mathrm{mM}(48 \mathrm{mg}$ dalam $50 \mathrm{ml} \mathrm{H}_{2} \mathrm{O}$ )

b. Larutan $1 \mathrm{mM}$ TPTZ dan dilarutkan dalam $\mathrm{HCl} 0.05 \mathrm{M}$ sebanyak 100 ml. Campuran dihomogenkan dengan cara divortex. 
Uji aktivitas antioksidan daun kersen (Muntingia calabura L.) dengan metode DPPH dan FRAP

Pembuatan seri konsentrasi kurva baku $\mathrm{FeSO}_{4}$

Dibuat larutan kurva baku besi(II) sulfat dengan seri konsentrasi 2, 4, 6, 8, dan 10 ppm. Ditimbang 25 $\mathrm{mg} \mathrm{FeSO}{ }_{4}$ dan dilarutkan dalam $50 \mathrm{ml}$ $\mathrm{H}_{2} \mathrm{O}$.

\section{Analisis Data}

Nilai persentase inhibisi yang diperoleh selanjutnya dimasukkan ke HASIL PENELITIAN

Tabel 1. Aktivitas antioksidan ekstrak etanol daun kersen dengan metode DPPH

\begin{tabular}{cccccc}
\hline Sampel & $\begin{array}{c}\text { Konsentrasi } \\
(\mathbf{p p m})\end{array}$ & $\begin{array}{c}\text { Log konsentrasi } \\
(\mathbf{X})\end{array}$ & $\begin{array}{c}\text { \%Pengikatan } \\
\mathbf{D P P H}\end{array}$ & $\begin{array}{c}\text { Probit } \\
(\mathbf{y})\end{array}$ & $\begin{array}{c}\mathbf{I C} \mathbf{C}_{50} \\
(\boldsymbol{\mu g} / \mathbf{m l})\end{array}$ \\
\hline Ekstrak & 2 & 0.301 & 13.24 & & \\
Etanol & 4 & 0.602 & 28.37 & 3.882 & \\
Daun & 6 & 0.788 & 41.61 & 4.431 & 6.8249 \\
Kersen & 8 & 0.903 & 53.72 & 4.78 & \\
& 10 & 1 & 66.33 & & \\
\hline
\end{tabular}

Tabel 2. Aktivitas antioksidan Ekstrak etanol daun kersen metode FRAP

\begin{tabular}{ccccc}
\hline Konsentrasi & Absorbansi & $\mathbf{X}$ & kadar eq $\boldsymbol{\mu M}$ Fe2+ & Nilai IC $_{50}$ \\
\hline 65.6 & 0.264 & 95 & 475 & \\
131.2 & 0.291 & 122 & 610 & \\
196.8 & 0.325 & 156 & 780 & $83.149 \mu \mathrm{M}$ \\
262.4 & 0.341 & 172 & 860 & \\
328 & 0.396 & 227 & 1135 & \\
\hline
\end{tabular}

Tabel 3. Identifikasi fitokimia Ekstrak etanol daun kersen

\begin{tabular}{ccc}
\hline Identifikasi Senyawa & Hasil & Keterengan \\
\hline Fenolik & Warna Hitam Pekat & Positif $(+)$ \\
Flavonoid & Warna Merah & Positif $(+)$ \\
Saponin & Terdapat Busa & Positif $(+)$ \\
\hline
\end{tabular}


Uji daya hambat ekstrak etil asetat daun binahong (Anredera coliforlia (Ten.) Steenis) terhadap pertumbuhan bakteri Staphylococcus aureus dan Escherichia coli.

PEMBAHASAN

Hasil pengukuran daya antioksidan ekstrak etanol daun kersen (Muntingia Calabura L.) dengan metode DPPH dapat dilihat pada Tabel 1. Pengujian metode DPPH berdasarkan kemampuan senyawa ini mendonorkan atom hidrogennya. Kemampuan ini berdasarkan kemampuan menghambat radikal bebas yang dihitung dalam \% inhibisi. Parameter yang dipakai untuk menunjukan aktivitas antioksidan adalah nilai Inhibition Concentration $\left(\mathrm{IC}_{50}\right)$ yaitu konsentrasi suatu zat antioksidan yang dapat menyebabkan 50\% DPPH kehilangan karakter radikal atau konsentrasi suatu zat antioksidan yang memberikan \% penghambatan 50\%. Nilai $I_{50}$ yang diperoleh dari ekstrak etanol daun kersen terhadap radikal DPPH $6.8249 \mu \mathrm{g} / \mathrm{ml}$. Nilai ini menurut Blois (1958), suatu senyawa memiliki antioksidan sangat kuat apabila $\mathrm{IC}_{50}$ kurang dari 50 ppm. Jika dibandingkan nilai tersebut maka ekstrak etanol daun kersen termasuk katagori sangat kuat. $^{7}$

Pengujian metode DPPH berdasarkan kemampuan senyawa ini mendonorkan atom hidrogennya. Kemampuan ini berdasarkan kemampuan menghambat radikal bebas yang dihitung dalam \% inhibisi. Parameter yang dipakai untuk menunjukan aktivitas antioksidan adalah harga Inhibition Concentration $\left(\mathrm{IC}_{50}\right)$ yaitu konsentrasi suatu zat antioksidan yang dapat menyebabkan 50\% DPPH kehilangan karakter radikal atau konsentrasi suatu zat antioksidan yang memberikan \% penghambatan $50 \%$. Nilai $I_{50}$ yang diperoleh dari ekstrak etanol daun kersen terhadap radikal DPPH $6.8249 \mu \mathrm{g} / \mathrm{ml}$. Nilai ini menurut Blois (1958), suatu senyawa memiliki antioksidan sangat kuat apabila $I_{50}$ kurang dari 50 ppm. Jika dibandingkan nilai tersebut maka ekstrak etanol daun kersen termasuk katagori sangat kuat.

Hasil pengujian metode FRAP dengan $\mathrm{FeSO}_{4}$ sebagai standar pada kondisi asam. Metode ini berdasarkan kemampuan mereduksi Fe3+ menjadi Fe2+ sehingga membentuk kompleks Fe3+ TPTZ dengan cara mendonorkan elektron yang dihasilkan dari senyawa antioksidan. Hasil pengujian diinterpretasikan dengan peningkatan absorbansi pada panjang gelombang $593 \mathrm{~nm}$ dan dapat disimpulkan sebagai jumlah $\mathrm{Fe} 2+$ (dalam mikromolar) ekuivalen dengan antioksidan standar.

Pada pengujian ini diperoleh $I_{50} 83.149 \mu \mathrm{M}$. Berdasarkan hasil uji 
Uji daya hambat ekstrak etil asetat daun binahong (Anredera coliforlia (Ten.) Steenis) terhadap pertumbuhan bakteri Staphylococcus aureus dan Escherichia coli.

identifikasi senyawa pada ekstrak etanol daun kersen secara kualitatif pada Tabel 3. Hasil identifikasi di atas menunjukkan bahwa ekstrak etanol positif mengandung fenolik, flavanoid dan saponin, yang mana ketiganya merupakan senyawa antioksidan.

\section{KESIMPULAN}

Hasil penelitian antioksidan disimpulkan bahwa : Kandungan senyawa metabiolit sekunder pada ektrak etanol daun kersen yaitu Fenolik , flavonoid, dan saponin. Ektrak etanol daun kersen menghansilkan nilai $\mathrm{IC}_{50} 6.8249$ ppm dan kuersetin $\mathrm{IC}_{50} 4.2354$ ppm. Dapat disimpulkan bahwa ekstrak daun kersen memiliki aktivitas antioksidan sangat kuat karena nilai IC50 $<50$ ppm. pada ekstrak daun kersen dengan Metode FRAP didapatkan nilai $\mathrm{IC}_{50} 83.149 \mu \mathrm{M}$ hal ini menunjukkan bahwa ekstrak etanol daun kersen memiliki aktivitas antioksidan yang kuat.

\section{DAFTAR PUSTAKA}

1. Kikuzaki H, Hisamoto M, Hirose $K$, Akiyama $\mathrm{K}$, and Taniguchi $\mathrm{H}$. Antioxidants properties of ferulic acid and its related compound. $\mathrm{J}$ Agric Food Chem 2002;50:21612168.

2. Hidajat B. Penggunaan Antioksidan pada Anak. Kapita Selekta IImu Kesehatan Anak. 2005.

3. Winarsi, H. Antioksidan Alami dan Radikal Bebas. Yogyakarta: Kanisius; 2007.

4. Cheng DS, Chen JJ, Hsinn HL. Activation of Nitric Oxide Signaling Pathway Mediates Hypotensive Effect of Muntingia calabura L. Leaf Extract. The American Journal of Chinese Medicine 2006;34 (5):857-72.

5. Zakaria ZA, Mohd NA, Hazalin N, et al,. Antinociceptive, antiinflammatory and antipyretic effects of Muntingia calabura aqueous extract in animal models. J Nat Med 2007;61:443-8.

6. Heinrich M, Barner J, Gibbons S, Williamson EM. Farmakognosi dan Fitoterapi. Jakarta: Penerbit Buku Kedokteran EGC;2009.

7. Blois MS. Antioxidant determination by the use of a stable free radical. Journal Nature 1958;181(4617): 1199-1200 